and development career in the Defence Research Laboratories/Establishments of the Research and Development Organization, as members of the Defence Science Service, India. Research and development activities of the Organization cover a wide field and embrace subjects as different as, for example, explosives and psychology. The researches are carried out either individually or by small teams in the Research and Development Laboratories/ Establishments which are spread throughout India and have considerable resources. The work is carried out in an atmosphere in which any enthusiastic person with a flair for research and inventive bent of mind would feel at ease. The defence scientists get opportunities of giving lectures, attending conferences in India and abroad, participating in symposia, exchanging ideas through contact with scientists in universities and other establishments, and of becoming known in the scientific world generally. They are encouraged to publish papers and also to submit theses for postgraduate degrees on their research work when this is not of a secret nature; patents are taken out whenever permissible. They may also be selected for attachment to establishments in India or abroad. Copies of the booklet are obtainable from the Research and Development Organization, Ministry of Defence, " $G$ " Block, Hastings Road, New Delhi-11.

\section{Analytical Methods for Fruit Juices}

A VALUABLE compilation on Analytical Methods for Fruit Juices has recently been produced in Paris by the International Federation of the Producers of Fruit Juices. It consists of methods of analysis acceptable to members from all countries affiliated to the Federation. The project has been the responsibility of the Scientific and Technical Commission of the Federation, and the collaborative work has been organized by the Sub-Committee on Unification of Analytical Methods, of which Prof. W. Diemair of the University of Frankfurt is the chairman. The brochure just published contains seven methods of analysis accompanied by drawings of all apparatus, graphs and tables necessary for the determination of specific gravity, alcohol, titratable acidity, sugar (before and after inversion), volatile acidity and total sulphur dioxide. The methods are presented in French, German and English. The complete compilation can be obtained, postage paid, for N.F. 15 , from Fédération Internationale des Producteurs de jus de fruits, 16 rue de la Chaussée d'Antin, Paris $\left(9^{\circ}\right)$.

\section{Excavation in New Zealand}

ANY attempt at getting a relative chronology in New Zealand is always welcome, even when the various layors are of no great antiquity. C. D. Smart and Roger C. Green have recently been excavating a stratified dune site at Tairua, Coromandel, New Zealand (Dominion Museum Records in Ethnology, Vol. 1, No. 7: A Stratified Dune Site at Tairua, Coromandel. By C. D. Smart and Roger C. Groen. With a specialist report by J. C. Yaldwyn. Pp. 243-266. Wellington, N.Z.: Dominion Museum, 1962). There is a spocialist report on the fauna found, by John Yaldwyn. The site is on the rocky islet of Paku at the mouth of the Tairua harbour. There are no less than 9 layers, but only two are of archæological interest. While there is no reason to think that any of the finds are earlier than the four. teenth century, the study of the so-called Archaic phase is much advanced as a result of this excava- tion. The artefacts include drills, obsidian knives, scrapers, etc. Among the bones, those of the moa have been identified.

\section{Australian Rock Carvings}

IN Australia the archæologist has gone ahead of the quaternary geologist. Much detailed study of the many rock carvings which occur has beon made, but very little in the way of a relative and actual chronology has yet been attempted. Among field workers the name of C. P. Mountford is well known. In the July issue of Man, together with Robert Edwards, he describes a number of engravings and carvings allegedly representing marine animals from sites very remote from the sea. It is suggested that they are of great antiquity, and date to a time when the sea was nearby. If the identifications are correct it is now up to the geologist to say when the sea actually was nearby, or whether folk-memory must be invoked.

\section{Preserving Rural Wales}

Testament to the work of so many devoted people in preserving the amenities of Wales, the combined annual reports for 1959-60 and 1960-61 of the Couneil for the Preservation of Rural Wales contain accounts of activities promoted to see that electricity transmissions are sited with discrimination, that town and country planning is carried out with a thought to the future, that historic buildings are not wantonly destroyed, that mineral undertakings are not only concerned with costs, that the beauty of the coasts are preserved and that adequate precautions are taken to prevent the spread of litter. (Pp. $93+2$ plates. Machynlleth, Montgomeryshire: Council for the Preservation of Rural Wales, 1962.) The reports also contain accounts of the best-kept village competitions. A sad feature of the reports is the record of the small number of members in Monmouthshire.

\section{The Weizmann Institute of Science}

THe report of scientific activities of the Weizmann Institute of Science for the two years 1960-61 gives short accounts of the work in progress in the various departments (Pp. 151. Rehovoth: The Weizmann Institute of Science, 1962). These include Applied Mathematics, Biophysics, Nuclear Magnetic Resonance, Nuclear Physics, Organic Chemistry, Plant Genetics, Polymer Research, X-Ray Crystallography, and the new Departments of Virology and Geneties, Cell Biology, Biodynamics and Carbohydrate Metabolism formed out of the Department of Experimental Biology during the period, as well as of the sections of Biochemistry, Electronics, Infra-red Spectroscopy, Isotope Research and Photochemistry and Spectroscopy. To each of these is attached a list of publications, and there are also reports from the Graduate School in the Natural Sciences and the Library with a list of scientific staff of the Institute. Among the numerous subjects under investigation it must suffice to mention the work on the biological synthesis of peptides and proteins, the catalysis of photophosphorylation by chloroplasts, on bacterial ribosomes, the physical chemistry and synthesis of ribonucleic acid, the synthesis and properties of low molecular weight peptides and polyamino-acids. polypeptidyl proteins, viruses and bacteria, synthetic polypeptide antigens, the structure and biological activity of proteins, biochemical aspects of urethane carcinogenesis, mechanism of epiloptic behaviour, 